\title{
Assessment of Plant Extracts and their In vitro Efficacy against Potato Early Blight Incited by Alternaria solani
}

\author{
Sumit Kumar* (D), Ram Chandra and Lopamudra Behera \\ Department of Mycology and Plant Pathology, Institute of Agricultural Sciences, Banaras Hindu University, \\ Varanasi - 221 005, Uttar Pradesh, India.
}

\begin{abstract}
Botanicals obtained from the plants are well known for the suppression of inimical plant pathogens. The present study explores the efficacy of five locally available plant extracts for their antifungal activity against the early blight of potato incited by Alternaria solani. The extracts include Datura stramonium, Allium sativum, Azadirachta indica, Eucalyptus globulus, and Lantana camara. All extracts reduced mycelial growth and conidial germination of $A$. solani. In vitro studies showed that extracts obtained from $A$. sativum and $A$. indica have significant inhibition of mycelial growth of $A$. solani $(88.80$ and $\mathbf{8 6 . 6 2}$ percent) at 20 percent concentration. Higher concentrations of $A$. sativum extract caused a higher reduction of $A$. solani radial growth on potato dextrose agar medium. Extracts obtained from $A$. sativum and $A$. indica at 20 percent concentration, were found most effective for inhibition of conidial germination ( 85.50 and 80.04 percent) respectively of $A$. solani. Observations by scanning electron microscope (SEM) showed dramatic alteration in $A$. solani hyphae collapsed and spores shrinked when treated with extract of $A$. sativum at a 20 per cent concentration. The qualitative and quantitative analysis of various phytochemicals like flavonoids, alkaloids, saponins, tannins, steroids, terpenoids, glycosides, and phenols was showed $A$. sativum extract better than all the other plant extracts. Observation also revealed that 20 percent concentration of garlic extract has potential to inhibit to A. solani.
\end{abstract}

Keywords: Alternaria solani, Plant extracts, Scanning Electron Microscope, Mycelial deformation

*Correspondence: sumit.kumar10@bhu.ac.in

(Received: May 12, 2021; accepted: July 28, 2021)

Abbreviations: ITCC- Indian Type Culture Collection, PDA- Potato Dextrose Agar, CRD-Completely Randomized Design, mm- milli meter, $\mathrm{ml}$ - milli litre, $\mu \mathrm{l}$ - micro litre, LCB- Lactophenol Cotton Blue, SEM-Scanning Electron Microscopy, M- molar, h- hour, nm- nano meter, mins- minutes, g- gram, mg- milligram, $\mathrm{N}$ - normal, ㅇ- Degree Celsius, ANOVA- Analysis of Variance, CD-Critical Difference.

Citation: Kumar S, Chandra R, Behera L. Assessment of Plant Extracts and their In Vitro Efficacy against Potato Early Blight Incited by Alternaria Solani. J Pure Appl Microbiol. 2021;15(3):1591-1601. doi: 10.22207/JPAM.15.3.55

(C) The Author(s) 2021. Open Access. This article is distributed under the terms of the Creative Commons Attribution 4.0 International License which permits unrestricted use, sharing, distribution, and reproduction in any medium, provided you give appropriate credit to the original author(s) and the source, provide a link to the Creative Commons license, and indicate if changes were made. 


\section{INTRODUCTION}

The potato (Solanum tuberosum L.), belong to family Solanaceae, is important tuber crops in sub-tropical and temperate regions also called as "King of vegetables"1. Potato is excellent source of vitamins, amino acids, carbohydrate, proteins, minerals and phytochemicals such as phenolic compound and carotenoids ${ }^{2}$. Presence of these nutrients reduces risk of several diseases such as cancer, diabetes, cataract and aging. This crop subjected to attack by more than hundred diseases including fungi, bacteria, virus and viroid. Among fungal diseases, early blight is one of the most detrimental fungal disease caused by Alternaria solani (Ell. and Mart.), present all over the world particularly potato growing Asian countries ${ }^{3}$. Primary infection by Alternaria solani can cause premature defoliation and small, irregular to circular dark brown spots on potato leaves. Lesions surrounded by a dark brown border resulting shallow, dry, corky rot produce on the older leaves considered as a foliar symptom. The disease can cause 70 to 80 percent yield loss in India ${ }^{4,5}$ and $80-100 \%$ worldwide ${ }^{6}$. Several fungicides are reported for the control of early blight, that is, chlorothalonil and triphenyl tin hydroxide ${ }^{7,8}$. In current scenario use of eco-friendly methods for management of plant diseases, to minimize synthetic chemicals and fungicides, caused environmental hazards to human and animals ${ }^{9,10}$. Resistant cultivars are an environment friendly method against this disease but resistant cultivars not durable for long time. Development of resistant cultivars is time consuming and expensive so there is need to develop holistic model to management early blight of potato ${ }^{11}$. Current study aimed to develop ecofriendly methods including botanicals for control early blight of potato. Use of botanicals or plant extract in plant disease management because they are eco-friendly, nonpolluting, cheaper, cost effective strategy, easily biodegradable and effective biocontrol methods, can be used in integration with other strategies for protection of crop plants ${ }^{12}$. The uses of plant extracts or phytochemicals in plant defence system against pathogen are not hazardous to environment, human and animals' health. Numerous plant pathogenic microorganisms are controlled by the application of various plant extracts such as Azadirachta indica, Allium sativum, Urtica spp., Ruta graveolens and Melaleuca alternifolia ${ }^{12}$. Many studies have shown that effects of plant extract for controlling the plant pathogens under in vitro conditions ${ }^{13,14}$. Chapagain et al. ${ }^{15}$ reported the use of saponin rich extract of Balanites aegyptica fruit against $A$. solani. Another study by Muto et al. ${ }^{16}$ tested 14 natural plant species against $A$. solani. Neem (Azadirachta indica) extract have antifunga $\left.\right|^{17}$, antibacterial ${ }^{18}$, and antivira ${ }^{19}$ properties. Plants possess numerous secondary metabolites compounds showing plant defense mechanisms against pathogen ${ }^{19}$. Aromatic secondary metabolites like terpenoids, flavonoids, tannins, glycosides, saponins, sterols and alkaloids are synthesized by the natural plant species $^{20}$. Availability of such bioactive compounds in plant species which are easily biodegradable and non-phytotoxic ${ }^{22,23}$. Current study explores plant extracts against $A$. solani under in vitro conditions.

\section{MATERIALS AND METHODS}

Plant extracts used in the study were obtained from Datura stramonium, Allium sativum, Azadirachta indica, Eucalyptus globulus and Lantana camera.

Plant materials and preparation of plant extracts

D. stramonium, A. indica, E. globulus and L. camera were collected from the agricultural research farm. Allium sativum was obtained from local vegetable market. Apparently fresh leaf material was collected and washed with distilled water and then surface sterilized with sodium hypochlorite $(\mathrm{NaClO}) 1$ percent solution for 2 mins then rinsed thrice with sterilized distilled water. Surface sterilized plant leaves were air dried in room temperature $\left(35^{\circ} \mathrm{C}\right)$ and homogenized to make 1 to $2 \mathrm{~mm}$ diameter fine powder using a grinder. Aqueous extracts were prepared by decoction method ${ }^{24}$. In brief $20 \mathrm{~g}$ dried fine powder of every plant sample was gently mixed with 80 $\mathrm{ml}$ of sterile distilled water and heated for 10 to 15 mins to remove contamination. Subsequently solution was filtrated through double layered muslin cloth, and finally centrifuged at 8,000 $\mathrm{rpm}$ for 25 mins. The obtained supernatant from previous step was filtered through Whatman filter paper No. 1 and sterilized in autoclaved. Sterilized 
solution considered as 100 percent concentration and preserved aseptically in separate sterile beakers at $4^{\circ} \mathrm{C}$ until experiment completion.

\section{Collection of pure culture of pathogen}

The authentic culture of $A$. solani was borrowed from the Indian Type Culture Collection, New Delhi, with the ITCC No. 3640. The fungus was sub-cultured and maintained on potato dextrose agar medium (PDA) at $4^{\circ} \mathrm{C}$. The pathogenicity was checked under in vitro condition by detached leaf assay (Fig.1).

\section{Evaluation of different plants extracts under in} vitro condition

To check the efficacy of five plant extracts against test pathogen under the in vitro condition was done with the help of poisoned food technique ${ }^{25}$. Different concentrations of test extracts, including 5, 10, 15 and 20 percent was added in PDA medium, mixed gently and 20 $\mathrm{ml}$ media poured in Petri dishes. PDA medium without plant extract was taken as control. Petri dishes containing different test extracts with PDA were placed at the centre of each plate with 5 $\mathrm{mm}$ diameter mycelial disk from 10 days old $A$. solani culture and plates were incubated at $27^{\circ} \mathrm{C}$ for one week and radial growth of mycelium was measured at 7 days after inoculation. This experiment was done with three replications for each treatment. To measure diameter of test pathogen colony by using two perpendicular lines in each Petri plates. The percent inhibition of test pathogen was assessed using the formula ${ }^{26}$.

$$
\mathrm{I}=\mathrm{C}-\mathrm{T} / \mathrm{C} \times 100
$$

Where, $\mathrm{l}=$ Per cent inhibition of mycelia growth $\mathrm{C}=$ Growth of mycelium in control $(\mathrm{mm})$ $\mathrm{T}=$ Growth of mycelium in treatment $(\mathrm{mm})$

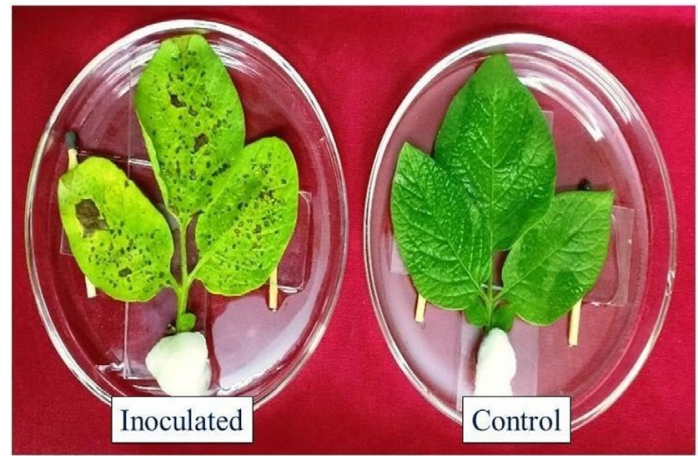

Fig. 1. Pathogenicity test: Leaves detached from plants 1 week after inoculation

\section{Preparation of conidial suspension}

Conidial suspension was prepared by following Stammler et al. ${ }^{27}$ with slight modification. $10 \mathrm{ml}$ sterilized distilled water was added to every Petri plate and 7-day old spore colonies were scraped with the help of rubber spatula. $10 \mathrm{ml}$ spore suspensions were made from each plate and conidia density was adjusted to $1.8 \times 10^{4}$ spores $\mathrm{ml}-1$ with the help of haemocytometer.

Inhibition of conidial germination of test pathogens

Five plant extracts were used to check the antifungal activity of aqueous extract on conidial germination of $A$. solani through microscopic slide technique with slight modification ${ }^{28}$. The plant extracts at four different concentrations $(5,10$, 15 and 20\%) was added as films on dried clean microscopic slide. $50 \mu \mathrm{l}$ conidial suspension was spread over these films and sterile distilled water slide served as a control. Every slide was transfer on a glass rod in a Petri dish under moist conditions and incubated for 3 days at $27^{\circ} \mathrm{C}^{29}$. Five slides were replicated three times for each concentration. Lactophenol cotton blue (LCB) was added to each slide to arrest conidia germination after incubation. Each slide was observed under a light microscope at $\times 400$ magnification to determine the germination rates of conidia. The experiment was repeated four times, with three replications every time. The percent inhibition of conidial germination for each treatment was assessed by the given formula:

Percent inhibition $=\mathrm{C}-\mathrm{T} / \mathrm{C} \times 100$

Where, $\mathrm{C}=$ Germinated conidia in control

$\mathrm{T}=$ Germinated conidia in treatment,

Mycelial deformation study by Scanning electron microscopy (SEM)

Mycelial disks treated with the plant extracts (Datura stramonium, Allium sativum, Azadirachta indica, Eucalyptus globulus and Lantana camera), among them A. sativum (20\%) and mycelial growth of $A$. solani was prepared by following procedure described by 30 with slight modifications. Mycelial disks were fixed with Karnovsky solution containing 2.5 percent glutaraldehyde, 2 percent paraformaldehyde in a $0.05 \mathrm{M}$ sodium cacodylate buffer $(\mathrm{pH}$ 7.2) for two days for SEM study. The mycelial disk gently washed 3 times by same buffer solution for 35 mins, followed by fixation done with 1 per cent 
osmium tetroxide solution for $2 \mathrm{~h}$ further washed thrice using sterililized distilled water and then dehydrated in a crescent acetone solution series that is, 30, 50, 70, 85, 90 and 100 percent. The samples were then dried in a critical point dryer (Bal-tec CPD 030) with carbon dioxide. Finally, the specimens were spotted on aluminium stubs and fixed with double sided black tape and coated with $20 \mathrm{~nm}$ gold layer with the help of vacuum evaporator (Bal-tec SCD 050). All specimens were visualized under Joel SEM- 6400JSM- 6360LV microscope (JEOL Ltd., Japan).

Qualitative analysis of phytochemical screening of different aqueous plant extract

The aqueous extract of five selected plants (D. stramonium, $A$. sativum, $A$. indica, $E$. globulus, and $L$. camera) was tested for antimicrobial secondary metabolites properties against test pathogen.

\section{Alkaloids}

$1.5 \mathrm{ml}$ extract was taken for alkaloid testing. $2 \mathrm{ml}$ of 1 per cent HCL solution thoroughly mixed with test extract. After mixing, solution was heated for to 2 mins and Mayer's reagent ( 6 drops) was added. Orange colour formation indicates the presence of alkaloids ${ }^{31}$.

\section{Flavonoids}

$1 \mathrm{ml}$ of aqueous solution of test extract was gently mixed with $1 \mathrm{ml}$ of 10 percent lead acetone. Develop yellow colour that showed the presence of flavonoids ${ }^{32}$.

\section{Saponins}

The procedure described by Saidulu et $\mathrm{al}^{33}$ was followed for the assay $2 \mathrm{ml}$ of aqueous test extract was taken and mixed with $6 \mathrm{ml}$ sterilized distilled water. Formation of forth was observed after 3 mins.

\section{Steroids}

$0.5 \mathrm{ml}$ test extract mixed with $2 \mathrm{ml}$ of acetic anhydride solution and further $2 \mathrm{ml} \mathrm{H}_{2} \mathrm{SO}_{4}$ was added to the reaction. The colour change violet to green or blue expressed the presence of steroids $^{34}$.

Tannins

Few drops of ferric chloride solution was mixed with test extract. Development of blackish colour expressed the presence of tannins in the extract ${ }^{33}$.

Terpenoids

$2 \mathrm{ml}$ test extract was mixed with $5 \mathrm{ml}$ of chloroform and heated for 5 mins and then allowed to dry. Further $2 \mathrm{ml}$ concentrated $\mathrm{H}_{2} \mathrm{SO}_{4}$ was added and again heated on low flame for 2 mins. Greyish colour develops to show presence of terpenoids ${ }^{33}$.

\section{Glycosides}

Each test extract was hydrolysed with hydrochloric acid and then neutralized with $\mathrm{NaOH}$ solution. Red colour developed after Fehling's solution A and B were mixed and this revealed that presence of glycosides ${ }^{35}$.

Phenols

$1 \mathrm{ml}$ of test extract was extracted in ethanol and then evaporated till dryness. After drying residue was dissolved in sterile distilled water and add $0.5 \mathrm{ml}$ Folin-ciocalteu reagent followed by $5 \mathrm{ml}$ of $20 \% \mathrm{Na}_{2} \mathrm{CO}_{3}$ solution. Bluish colour developed reveals that presence of phenols ${ }^{36}$.

Quantitative analysis of phytochemical screening of different aqueous plant extract

Alkaloids test extract weighed $2 \mathrm{ml}$ in to $250 \mathrm{ml}$ capacity sterile conical flask. $200 \mathrm{ml}$ glacial acetic acid in methanol was added and mixed gently. Flask were covered with aluminium foil and incubated at $35^{\circ} \mathrm{C}$ for $4 \mathrm{~h}$. Then filtered obtained from previous step was and concentrated in water bath. Further few drops of concentrated $\mathrm{NH}_{4} \mathrm{OH}$ were added into test extract for precipitation. The precipitate was extracted, washed with dilute $\mathrm{NH}_{4} \mathrm{OH}$ and again filtered. The remaining residue was calculated in term of percentage ${ }^{37}$.

\section{Flavonoids}

$10 \mathrm{~g}$ each test extract was extracted with the $100 \mathrm{ml}$ of 80 percent ethanol solution at $37^{\circ} \mathrm{C}$. The obtained solution was filtered by the help of Whatman filter paper No. 42 and then filtrate placed into water bath for dryness. The wright of solution and percentage quantity was calculated according ${ }^{38}$.

\section{Saponins}

20 g each dried sample and 20 per cent ethanol was added. Sample was incubated in water bath for $1 \mathrm{~h}$ with constant shaking. The solution filtered and residue again extracted with $200 \mathrm{ml}$ of 20 percent methanol. The extracts were allowed to be reduced up to $40 \mathrm{ml}$ in water bath. Concentrated solution placed into a $250 \mathrm{ml}$ capacity separatory funnel, $20 \mathrm{ml}$ diethyl ether was added and then vigorous shaking. Ether layer was 
formed and discarded, and purification process was repeated. After purification, $60 \mathrm{ml}$ n-butanol was added and further extract were washed thoroughly twice with $15 \mathrm{ml}$ of 5 percent $\mathrm{NaCl}$. The solution was heated for evaporation, and then dried in hot air oven. Weighed and percentage was calculated of saponin ${ }^{39}$.

Steroids

$1 \mathrm{gm}$ sample was crushed in $20 \mathrm{ml}$ of methanol and filtered. $2 \mathrm{ml}$ filtrate was taken and add $5 \mathrm{ml}$ of chromagen solution. The solution was incubated at $35^{\circ} \mathrm{C}$ for 30 mins. Absorbance was recorded at $550 \mathrm{~nm}$ wavelength ${ }^{40}$.

Tannins

$500 \mathrm{mg}$ samples were added in $50 \mathrm{ml}$ distilled water. The solution allows to shaken for 60 mins and filtered. $10 \mathrm{ml}$ filtrate was pipetted out into the new test tube and $2 \mathrm{ml} 0.1 \mathrm{M}$ ferric chloride in $0.1 \mathrm{~N} \mathrm{HCl}$ was added along with 0.008 $\mathrm{M}$ potassium ferrocyanide. The final absorbance was recorded at $120 \mathrm{~nm}$ wavelength ${ }^{41}$.

Terpenoids

$1 \mathrm{~g}$ of extracts were taken, crushed in 50 $\mathrm{ml}$ of methanol and filtered. $2.5 \mathrm{ml}$ filtrate was taken and $2.5 \mathrm{ml}$ of $5 \%$ phosphomolybdic acid was added afterward $2.5 \mathrm{ml}$ of concentrated $\mathrm{H}_{2} \mathrm{SO}_{4}$ were added. The mixture was incubated at $35^{\circ} \mathrm{C}$ for 30 mins. The final observance was recorded at $700 \mathrm{~nm}$ wavelength ${ }^{40}$.

\section{Glycosides}

$1 \mathrm{~g}$ test samples were taken and macerated with $50 \mathrm{ml}$ of methanol and filtered. $1 \mathrm{ml}$ supernatant was taken and $4 \mathrm{ml}$ of alkaline pirate solution was added. The reaction mixture was heated for 5 mins and allowed to cool. The observance was recorded at $490 \mathrm{~nm}$ wavelength ${ }^{34}$. Phenols: $2 \mathrm{~g}$ test samples were taken in $100 \mathrm{ml}$ diethyl ether solution and allowed to defat with help of Soxhlet apparatus for 2 to $3 \mathrm{~h}$. Defatted solution was heated with $50 \mathrm{ml}$ of ether for 15 mins. $10 \mathrm{ml}$ of reaction was pipetted out into 50 $\mathrm{ml}$ capacity flask and $15 \mathrm{ml}$ sterile distilled water was added. Further, $2 \mathrm{ml}$ of $\mathrm{NH}_{4} \mathrm{OH}$ solution and $2 \mathrm{ml}$ of concentrated amyl alcohol were added. The reaction was incubated at $35^{\circ} \mathrm{C}$ for 30 mins. Absorbance was recorded at $505 \mathrm{~nm}$ wavelength ${ }^{41}$. Statistical analysis

The analysis of data with help of oneway analysis of variance (ANOVA) and compared means for significance at $p$ level of $\leq 0.05$ through 


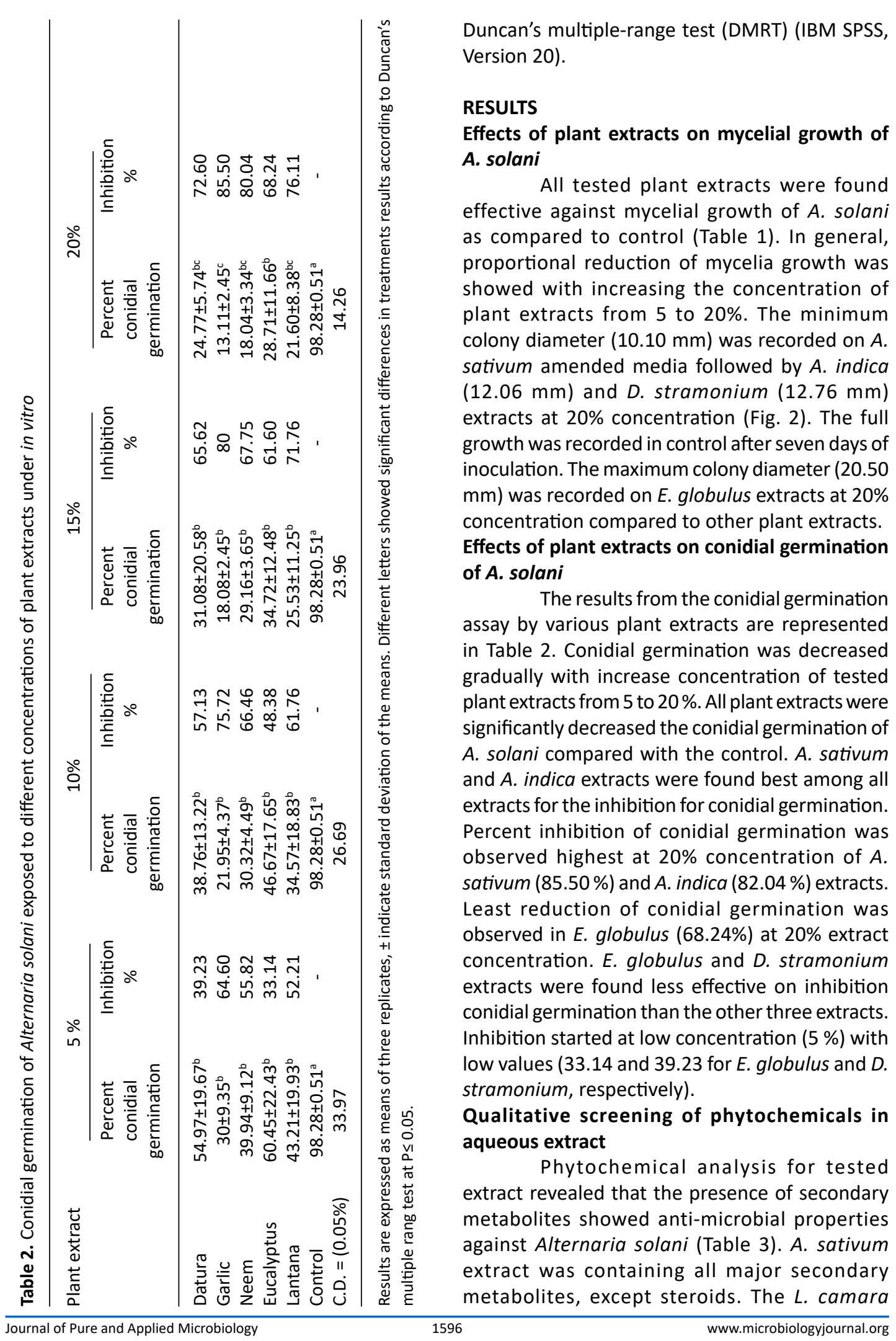


Table 3. Qualitative analysis of phytochemicals in aqueous plant extracts

\begin{tabular}{|c|c|c|c|c|c|c|}
\hline No. & Phytochemicals & $\begin{array}{c}\text { Datura } \\
\text { stramonium }\end{array}$ & $\begin{array}{l}\text { Allium } \\
\text { sativum }\end{array}$ & $\begin{array}{c}\text { Azadirachta } \\
\text { indica }\end{array}$ & $\begin{array}{c}\text { Eucalyptus } \\
\text { globulus }\end{array}$ & $\begin{array}{l}\text { Lantana } \\
\text { camara }\end{array}$ \\
\hline 1. & Flavonoids & + & + & + & + & + \\
\hline 2. & Alkaloids & + & + & + & - & - \\
\hline 3. & Saponins & + & + & + & + & + \\
\hline 4. & Tannins & - & + & + & - & + \\
\hline 5. & Steroids & + & + & + & + & + \\
\hline 6. & Terpenoids & + & + & + & - & + \\
\hline 7. & Glycosides & + & + & + & + & - \\
\hline 8. & Phenols & - & + & + & + & + \\
\hline
\end{tabular}

$(+)$ : Presence of phytochemicals, (-): Absence of phytochemicals

extract possesses flavonoids, saponins, tannins, steroids, terpenoids, phenols but alkaloids and glycosides were absent. Eglobulus and $D$ stramonium contains the secondary metabolites like flavonoids, alkaloids, saponins, tannins, steroids, terpenoids, glycosides and phenols except alkaloids, terpenoids, tannins and phenols. Further, $A$. indica extract contains flavonoids, alkaloids, glycosides and phenols except other secondary metabolites like saponins, tannins, steroids and terpenoids.

Quantitative assessment of phytochemicals of different aqueous plant extract

The results represented in Table 4 for quantitative analysis of phytochemicals in tested

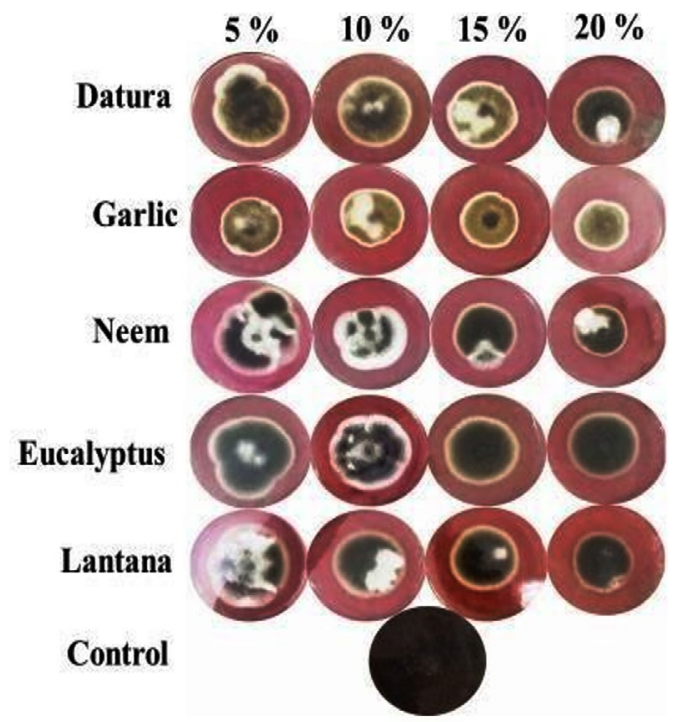

Fig. 2. Mycelial growth of Alternaria solani at different concentration of plant extracts after seven days of inoculation plant extracts. The results revealed that maximum flavonoids content $(1.12 \%)$ was recorded in $A$. sativum followed by $A$. indica $(0.90 \%)$, and $L$. camara $(0.82 \%)$. A. sativum and $A$. indica extracts content huge amounts of secondary metabolites like alkaloids ( 0.93 and $0.89 \%$ ), tannins ( 12.14 and $8.23 \%$ ), phenols ( 0.81 and $0.64 \%$ ), steroids ( 0.85 and $0.81 \%$ ), terpenoids ( 2.31 and $2.22 \%$ ), and glycosides (2.76 and $2.61 \%$ ) respectively. However, saponins content was higher in $A$. sativum and D. stramonium (3.45 and $2.25 \%$ ) respectively. The E. globulus extracts was recorded minimum concentration of secondary metabolites including flavonoids $(0.49 \%)$, alkaloids $(0.21 \%)$, saponins (1.45\%), and tannins (4.87\%). Phenols (0.37 $\%)$, steroids $(0.53 \%)$, terpenoids (1.89\%) and glycosides $(2.21 \%)$, were found low concentration in $D$. stramonium extracts.

\section{Mycelium and conidia of $A$. solani under scanning electron microscopy}

Based on mycelial growth assay results, A. sativum extract was further investigated by scanning electron microscopy (SEM) against $A$. solani. Results obtained from SEM revealed that the hyphae of the pathogen exposed to $A$. sativum plant extract were collapsed, short branching, and caused curling in the hyphae, whereas no such changes were observed in the hyphae developed in the control treatment. Moreover, A. sativum extract results revealed that no conidia formation, shorter germ tubes, and caused shrinking in conidia. The untreated control did not cause any spore shrinking (Fig.3). 


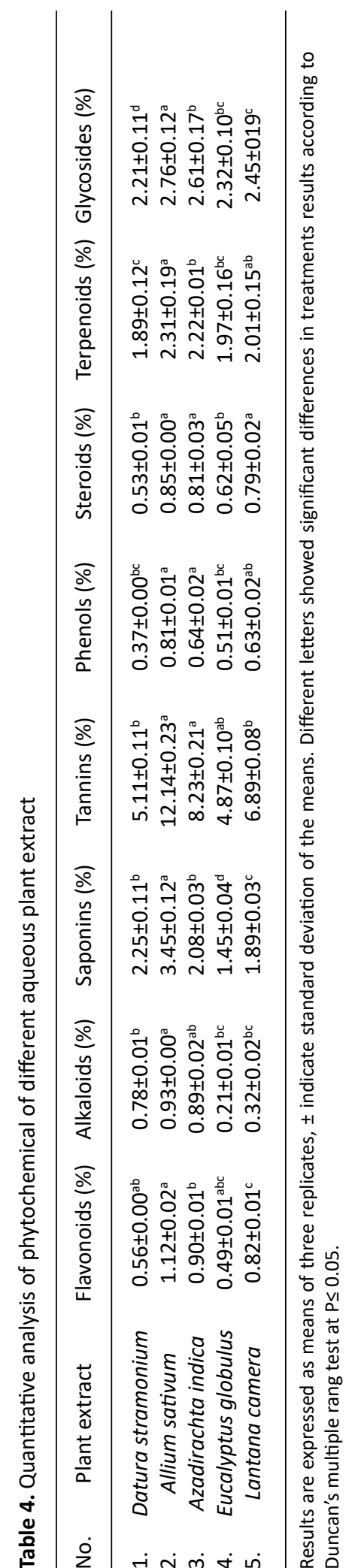

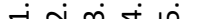

\section{DISCUSSION}

In the current study we demonstrated that antimicrobial compounds were present in five plant extracts. The plant extracts inhibited mycelial growth of $A$. solani and conidial germination under in vitro condition. Various plants have been reported to comprise antifungal activity and they have shown encouraging results under in vitro conditions $\mathrm{s}^{42-45}$. The current in vitro study revealed that among the five tested plant extracts, $A$. sativum and $A$. indica resulted significant reduction in conidial germination and growth of $A$. solani. Gradual increase in concentrations of plant extracts represents gradual decrease in conidial germination of the pathogen. Plant extracts evaluated against $A$. solani in the current study also showed significant results ${ }^{46}$. Reports suggested antifungal activity of $A$. sativum against harmful phytopathogens $s^{47,48}$. Significant inhibition was observed with $A$. sativum extract at higher concentration (20\%) against the $A$. solani. Investigation of the efficacy of $A$. sativum by Scanning Electron Microscope also showed higher inhibition of test fungus and this finding is in agreement with that of Baka and Rashad ${ }^{49}$. Plant extracts used at higher concentration have capability to reduce growth of phytopathogenic fungi ${ }^{50}$. Plant extracts from $A$. sativum also comprised botanical compounds such as Allicin, which checked the growth of pathogen mycelium and also inhibited spore germination ${ }^{51}$.

Plant extracts were analyzed for potential antifungal phytochemicals. Various secondary metabolites were detected including alkaloids, flavonoids, saponins, tannins, phenols, terpenoids, glycosides and steroids. The extract from $A$. sativum was most potential in inhibiting the growth of $A$. solani compared to other plant extracts, because presence of phytochemicals in huge amounts. Plant derived secondary metabolites like flavonoids have antifungal, antibacterial and antiviral activity used in higher concentrations ${ }^{52}$. Most of these phytochemicals have antimicrobial activity in response to disease causing detrimental microbes like fungi, bacteria and virus ${ }^{53}$. Various other studies have reported efficacy of phytochemicals against $A$. solani ${ }^{54,55,43}$. Plants are huge in the array of secondary metabolites which have been implicated for their in vitro antifungal properties. Phytochemicals like substances play a pivotal role 

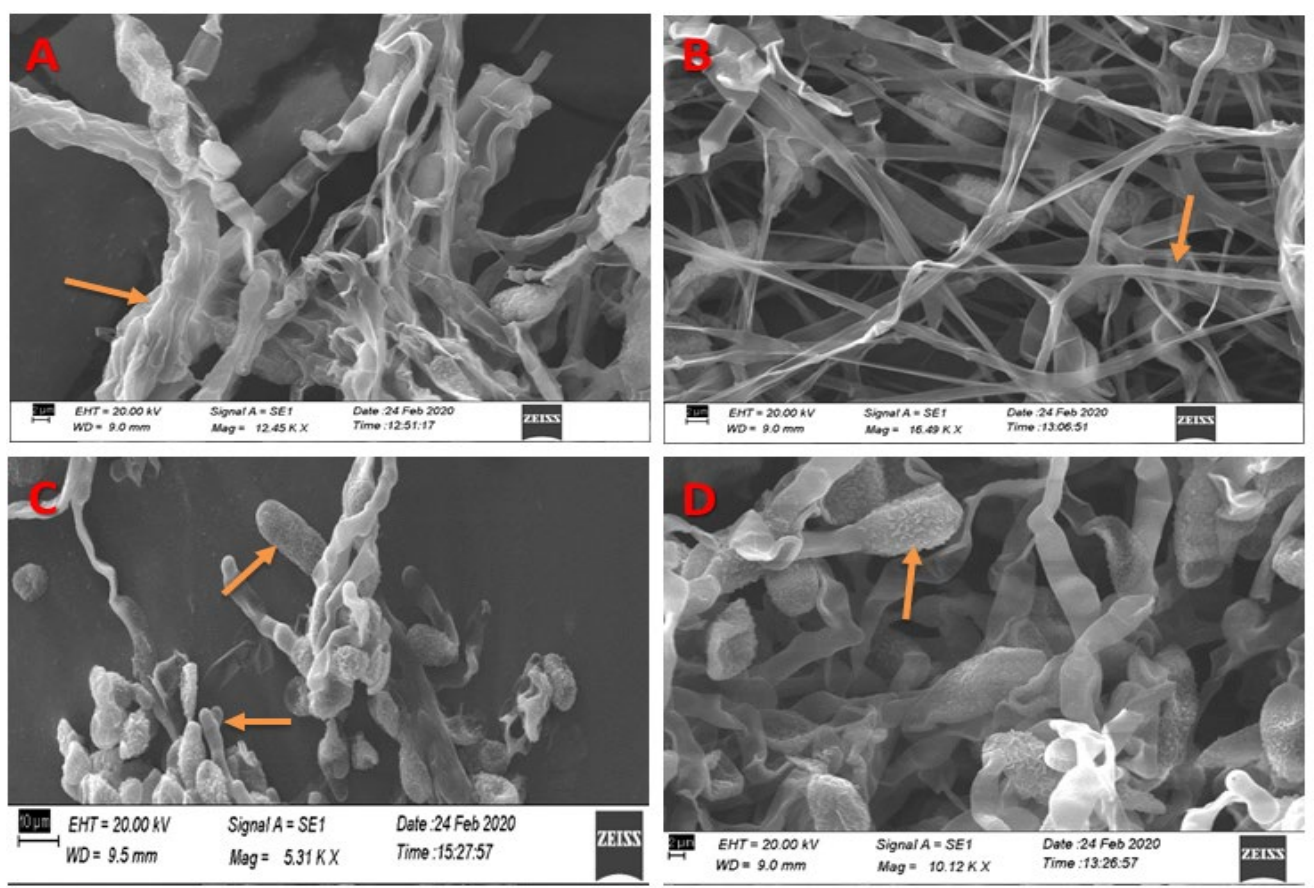

Fig. 3. SEM micrographs showing effects of $A$. sativum extract on the morphology and conidia of Alternaria solani. (A) Hyphae after treated with $A$. sativum extract (20\%) observed collapsed hypha (arrow). (B) Hyphae of untreated treatment showing normal hypha (arrow). Bar $=2.0 \mu \mathrm{m}$.

(C) Continuation in the sentence shrinking and an arrow shows the small rings (septa) formation on conidia. (D) In control treatment showing no deformity.

in plant defense mechanism against invasion by harmful microorganism and insects ${ }^{56}$.

\section{CONCLUSION}

The present investigation showed that among five tested plant extracts, $A$. sativum and $A$. indica resulted significant reduction in mycelial growth of $A$. solani, reduction in conidial germination or no conidia formation, formation of shorter germ tubes and shrinking in conidia. Various secondary metabolites were also detected in the plant extracts. The research concludes that plant extracts such as Allium sativum, Azadirachta indica, Datura stramonium, Eucalyptus globulus, and Lantana camara at higher concentrations have capability to reduce pathogen growth and spore germination of inimical plant pathogenic fungi because of presence of several antifungal secondary metabolites such as alkaloids, saponins, terpenoids, flavonoids and phenols. This biocontrol method is environmentally safe, eco-friendly, long lasting, and minimizing the use of hazardous chemicals for management of Alternaria solani in potato.

\section{ACKNOWLEDGMENTS}

The authors are grateful to Professor and Head, Department of Mycology and Plant Pathology, Institute of Agricultural Sciences, Banaras Hindu University, Varanasi for providing all necessary facilities to conduct experiments.

\section{CONFLICT OF INTEREST}

The authors declare that there is no conflict of interest.

\section{AUTHORS' CONTRIBUTION}

SK was responsible for methodology, investigation and wrote the manuscript. LB helped in performing data analysis. RC supervised the experiment and reviewed the manuscript and made suitable changes. The author(s) read and approved the final manuscript. 


\section{FUNDING}

None.

\section{DATA AVAILABILITY}

All datasets generated or analyzed during this study are included in the manuscript.

\section{ETHICS STATEMENT}

Not applicable.

\section{REFERENCES}

1. Hijmans RJ, Spooner DM. Geographic distribution of wild potato species. American Journal of Botany. 2001;88(11):2101-2112. doi: 10.2307/3558435

2. Nunn N, Qian N. The potato's contribution to population and urbanization: evidence from a historical experiment. Q J Econ. 2011;126(2):593-650. doi: 10.1093/qje/qjr009

3. Van der Waal JE, Korsten L, Aveling TAS. A review of early blight of potato. African Plant Protection. 2001;7(2):91-102. doi: 10.10520/EJC87837

4. Yanar Y, Gokce A, Kadioglu I, Cam H, Whalon M. In vitro antifungal evaluation of various plant extracts against early blight disease (Alternaria solani) of potato. Afr J Biotechnol. 2011;10(42):8291-8295. doi: 10.5897/ AJB11.241

5. Dey U, Das A. Management of potato early blight. Sci-Tech, The Hindu. 2015.

6. Singh A, Gaurav SS, Shukla G, Rani P, Kumar B, Kumar A. Evaluation of mycogenic silver and zinc oxide nanoparticles as potential control agent against early blight (Alternaria solani) of potato (Solanum tuberosum L.). Journal of Advanced Scientific Research.2020;11(2):164-172

7. Rodriguez MAD, Brommonschenkel SH, Matsuoka K, Mizubuti ESG. Components of resistance to early blight in four potato cultivars: Effect of leaf position. $J$ Phytopath. 2006;154(4):230-235. doi: 10.1111/j.14390434.2006.01089.x

8. Gondal AS, Ijaz M, Riaz K, Khan AR. Effect of different doses of fungicide (Mancozeb) against Alternaria leaf blight of tomato in Tunnel. Plant Pathol Microbiol. 2012;3:125. doi: 10.4172/2157-7471.1000125

9. Pasche JS, Piche LM, Gudmestad NC. Effect of the F129L mutation in Alternaria solani on fungicides affecting mitochondrial respiration. Plant Dis. 2005;89(3):269278. doi: 10.1094/PD-89-0269

10. Rosenzweig N, Atallah ZK, Olaya G, Stevenson WR. Evaluation of Qol fungicide application strategies for managing fungicide resistance and potato early blight epidemics in Wisconsin. Plant Dis. 2008;92(4):561-568. doi: 10.1094/PDIS-92-4-0561

11. Jindo K, Evenhuis A, Kempenaar C, et al. Holistic pest management against early blight disease towards sustainable agriculture. Pest Management Science. 2021;1-10. doi: 10.1002/ps.6320

12. Gurjar MS, Ali S, Akhtar M, Singh KS. Efficacy of plant extracts in plant disease management. Agric Sci. 2012;3:425-433. doi: 10.4236/as.2012.33050
13. Mishra AK, Mishra A, Kehri HK, Sharma B, Pandey AK, Inhibitory activity of Indian spice plant Cinnamomum zeylanicum extracts against Alternaria solani and Curvularia lunata, the pathogenic dematiaceous moulds. Ann Clin Microbiol Antimicrob. 2009;8:9. doi: 10.1186/1476-0711-8-9

14. Talibi I, Askarne L, Boubaker $\mathrm{H}$, et al. Antifungal activity of some Moroccan plants against Geotrichum candidum, the causal agent of post-harvest citrus sour rot. Crop Prot. 2012;35:41-46. doi: 10.1016/j. cropro.2011.12.016

15. Chapagain BP, Wiesman Z, Tsror L. In vitro study of the anti-fungal activity of saponin- rich extracts against prevalent phytopathogenic fungi. Ind Crops Prod. 2007;26(2):109-115. doi: 10.1016/j. indcrop.2007.02.005

16. Muto M, Takahashi H, Ishihara K, Yuasa H, Huang JW. Antimicrobial activity of medicinal plants used by indigenous people in Taiwan. Plant Pathol. Bull., 2005, 14, 13- 24. https://www.cabdirect.org/cabdirect/ abstract/20053087236.

17. Murthy SP, Sirsi M. Studies on Melia azadirachta Poot I: Antibacterial, antifungal and antitubercular activity of neem oil and its fractions. Symp. Utilization. Indian Med. PI., Lucknow. 1957.

18. Chopra IC, Gupta KC, Nazir BN. Preliminary study of antibacterial substance from Melia azadirachta. Indian J Med Res. 1952;40:511-515.

19. Rao AR, Sukumar S, Paramsivam TB, Kamalakshi S, Prashuraman AK, Shanth M. Study of antiviral activity of tender leaves of Margosa tree (Melia azadirachta) on vaccinia and variola virus: a preliminary report. Indian J Med Res., 1969; 57(3):495-502.

20. Das K, Tiwari RK, Shrivastava DK. Techniques for evaluation of medicinal plant products as antimicrobial agent: current methods and future trends. J Med Plants Res. 2010;4(2):104-111. doi: 10.5897/JMPR09.030.

21. Dahanukar SA, Kulkarni RA, Rege NN. Pharmacology of medicinal plants and natural products. Indian J Pharmacol. 2000;32(4):81-118.

22. Al-Askar AA, Rashad YM. Efficacy of some plant extracts against Rhizoctonia solani on pea. Journal of Plant Protection Research. 2010;50(3):239-243. doi: 10.2478/v10045-010-0042-0

23. Gahukar RT. Evaluation of plant-derived products against pests and diseases of medicinal plants: a review. Crop Prot. 2012;42:202-209.

24. Davis H. Bentley's text book of pharmaceutics. 6th ed. London: T. Baillier. 1956.

25. Nene YL, Thapliyal PN. Fungicides in Plant Disease Control. 3rd edition. Oxford and IBH Publishing Company, New Delhi, India. 1993.

26. Vincent JM. Distortion of fungal hyphae in the presence of certain inhibitors. Nature. 1947;159(4051):850. doi: 10.1038/159850b0

27. Stammler G, Bohme F, Philippi J, Miessner S, Tegge V. Pathogenicity of Alternaria spp. on potatoes and tomatoes. Special Report Applied Plant R. 2014;16:8596.

28. Rodrigues TT, Maffia LA, Dhingra OD, Mizubuti ESG. In vitro production of conidia of Alternaria solani. Tropical Plant Pathol. 2010;35(4):203-212. doi: 10.1590/S1982- 


\section{1}

29. Cao KQ, van Bruggen AHC. Inhibitory efficacy of several plant extracts and plant products on Phytophthora infestans. Journal of Agricultural University of Hebei. 2001;24:91-98.

30. Bozzola JJ, Russel LD. Electron Microscopy. 2nd ed. Boston: Jones and Bartlett Publishers. 1998.

31. Rasool R, Ganai BA, Akbar S, Kamili AN, Masood A. Phytochemical screening of Prunella vulgaris L. - an important medicinal plant of Kashmir. Pak J Pharm Sci. 2010;23(4):399-402.

32. Harborne JB. Phytochemical methods. A guide to modern techniques of plant analysis. 3rd ed. London: Chapman and Hall. 1998.

33. Saidulu C, Venkateshwar C, Gangadhar R. Preliminary phytochemical studies of medicinal plant drug: Withania somnifera L. Biolife. 2014;2(1):306-312.

34. Vijay P, Nivedita BA, Bellundagi A. Ethnobotany and qualitative phytochemical analysis of some Indian medicinal plants. Int J Chem Pharm Sci. 2013;4:59-63.

35. Zeb A, Sadiq A, Ullah F, Ahmad S, Ayaz M. Phytochemical and toxicological investigations of crude methanolic extracts, subsequent fractions and crude saponins of Isodon rugosus. Biol Res. 2014;47:57. doi: 10.1186/0717-6287-47-57

36. Sadasivam S, Manickam A. Biochemical Methods, New Age International Publishers (P) Ltd., New Delhi, India. 1996.

37. Harborne JB. Methods of plant analysis. In Phytochemical Methods. Chapman and Hall, London. 1973. doi: 10.1007/978-94-009-5921-7_1

38. Bohm BA, Kocipai- Abyazan R. Flavonoid and condensed tannins from the leaves of Vaccinum raticulation and Vaccinum calcyimium (Ericaceas). Pacific Sci. 1994;48:458-463.

39. Obadoni BO, Ochuko PO. Phytochemical studies and comparative efficacy of the crude extract of some homeostatic plants in Edo and Delta states of Nigeria. Global J Pure App/ Sci. 2002;8(2):203-208. doi: 10.4314/gjpas.v8i2.16033

40. Ekwueme FN, Nwodo OFC, Joshua PE, Nkwocha C, Eluka PE. Qualitative and quantitative phytochemical screening of the aqueous leaf extract of Senna mimosoides: Its effect in in vivo leukocyte mobilization induced by inflammatory stimulus. Int.J.Curr.Microbiol. App.Sci. 2015;4(5):1176-1188.

41. Van-Burden TP, Robinson T. The biochemistry of alkaloids, 2nd ed. Springer, Heidelberg, New York. 1981.

42. Ahmad F, Raziq F, Ullah $\mathrm{N}$, Khan $\mathrm{H}$, Din, N. In vitro and in vivo bio-assay of phytobiocidal effect of plant extracts on Alternaria solani causing agent of early blight disease in tomato. Archives of Phytopathology and Plant Protection. 2017;50(11):568-583. doi: 10.1080/03235408.2017.1352247

43. Paola DD, Andrea C, Diego A, Patricia L, Fernando F, Marco DR. Antifungal Activity of Medicinal Plant Extracts Against Phytopathogenic Fungus Alternaria spp. Chilean Journal of Agricultural
Research. 2011;71(2):231-239. doi: 10.4067/S071858392011000200008

44. Khafari A, Bahraminejad S, Abbasi S. Evaluation of the anti-Alternaria solani activity of Allium hirtifolium Boiss. Pak. J. Bot. 2014;46(2):741-747.

45. Nivedha M, Ebenezar EG, Kalpana K, Arun KR. In vitro antifungal evaluation of various plant extracts against leaf blight disease of Jasminum grandiflorum caused by Alternaria alternate (Fr.) Keissler. J Plant Pathol. 2019;8(3):2143-2147.

46. Rex B, Prabhu S, Kumar JS. Antifungal efficacies of plant extracts against Alternaria solani (Ellis and Martin) jones and grout under in vitro condition. Ann Phytomed. 2019;8(1):148-152. doi: 10.21276/ ap.2019.8.1.19

47. Alkhail AA. Antifungal activity of some extracts against some plant pathogenic fungi. Pak J Biol Sci. 2005;8(3):413-417.

48. Taskeen-U-Nisa, Wani AA, Bhat MY, Pala SA, Mir RA. In vitro inhibitory effect of fungicides and botanicals on mycelial growth and spore germination of Fusarium oxysporum. J Biopestic. 2011;4(1):53-56.

49. Baka ZA, Rashad YM. Alternative control of early blight of tomato using plant extracts from Acacia nilotica, Achillea fragrantissima and Calotropis procera. Phytopathologia Mediterranea. 2016;55(1):121-129. doi: 10.14601/Phytopathol_Mediterr-17161

50. Chiejina NV, Ukeh JA. Antimicrobial properties and phytochemical analysis of methanolic extracts of Aframomum melegueta and Zingiber officinale on fungal diseases of tomato fruit. J Nat Sci Res. 2012;2(6):10-15.

51. Perello $\mathrm{A}$, Noll $\mathrm{U}$, Slusarenko AJ. In vitro efficacy of $A$. sativum extract to control fungal pathogens of wheat. J Med Plants Res. 2013;7(24):1809-1817. doi:10.5897/ JMPR12.511.

52. Orhan DD, Ozcelik B, Ozgen S, Ergun F. Antibacterial, antifungal, and antiviral activities of some flavonoids. Microbiol Res. 2010;165(6):496-504. doi: 10.1016/j. micres.2009.09.002

53. Din N, Ahmad M, Siddique M, et al. Phytobiocidal management of bacterial wilt of tomato caused by Ralstonia solanacearum (Smith) Yabuuchi. Span J Agric Res. 2016;14(3):e1006. doi: 10.5424/sjar/20161439012

54. Nashwa SMA, Abo-Elyousr KAM. Evaluation of various plant extracts against the early blight disease of tomato plants under greenhouse and field conditions. Plant Protection Sci. 2012;48:74-79. doi: 10.17221/14/2011PPS

55. Ravikumar MC, Garampalli RH. Antifungal activity of plants extracts against Alternaria solani, the causal agent of early blight of tomato. Archives of Phytopathology and Plant Prot. 2013;46(16):18971903. doi: $10.1080 / 03235408.2013 .780350$

56. VanEtten HD, Mansfield JW, Bailey JA, Farmer EE. Two classes of plant antibiotics: phytoalexins versus phytoanticipins. Plant Cell. 1994;6(9):1191-1192. doi: $10.2307 / 3869817$ 